\title{
China's weapons transfer in the Western hemisphere
}

\author{
Dr Carlos Solar \\ Lecturer \\ Department of Sociology \\ University of Essex \\ carlos.solar@essex.ac.uk \\ wWw . carlossolar. com
}

Pre-publication manuscript. This version may contains pre-proofs typos. Please use the link and reference below to cite the published version.

Carlos Solar (2020) China's weapons transfer in the Western hemisphere, Journal of Strategic Studies, 43:2, 217-244, DOI:10.1080/01402390.2019.1659782 


\title{
China's Weapons Transfer in the Western Hemisphere
}

\begin{abstract}
What characterizes China's weapons diplomacy and how does it unfold in the current security scenario in the Western Hemisphere? This article argues that Sino arms deliveries have arrived in the region together with the expansion of commerce and trade routes as evidenced in Africa, Asia, and the Middle East. In Latin America and the Caribbean, states seek to buy weapons in light of contentious border hot spots and intrastate rampant violence. China is a willful seller and, to accomplish this, it has developed a weapons transfer policy taking advantage of the post-hegemony of the United States. The article argues that Beijing's successes could reverse due to the lack of interstate armed conflict, and the less belligerent military missions adopted by the armed forces. Yet, Chinese arms transfers in the Western Hemisphere and other parts of the developing world reveal a complex security governance regime where the military, industry, and diplomatic policy communities interact.
\end{abstract}

Keywords: Foreign Policy; International Relations; Weapons Industry; Arms Transfers.

\section{Introduction}

The changing political economy of the defense industry has allowed Chinese conglomerates to expand globally. Countries in Sub-Saharan Africa, the Middle East, Asia, and Latin America can now buy Sino-manufactured weapons and technological know-how backed by gross economic booms and off-budget expenditure. ${ }^{1}$ For many developing states, Chinese deliveries of artillery systems, aircraft, helicopters, mortar and missile launchers are accessible, reliable, and ready-to-use. ${ }^{2}$ China's arms diplomacy, however, confronts a challenging scenario in some parts of the world. The article explores the Latin American and Caribbean case study in order to shed light on a par- 
ticular puzzle: what characterizes China's current arms transfer diplomacy and how does it unfold in the context of a developing region? Understanding the current strategic scenario in the Western Hemisphere advances the argument that China's arms transfer and foreign relations with Latin America are the result of a particular security and foreign policy tradeoff. We know so far that the United States' post-hegemony over the region has enhanced the geographic expansion of Beijing, particularly in terms of trade and investment. ${ }^{3}$ What remains understudied, however, is what this means for the developing Americas' security order in the post-Cold War era. The embrace of Chinese influence has provided a mix of outcomes. The Belt and Road Initiative enforced by President Xi Jinping cares greatly to expand its influence in developing countries; an overall strategy also emphasized in security and military affairs. Paradoxically, when it comes to building up trade and security alliances, Latin American states have dual-channels that benefit from simultaneous links with both sides. States can now choose from Eastern and Western competitive international market economies that put a range of commercial opportunities at their disposal, including weapons suppliers. ${ }^{4}$

China has sought for conventional arms transfers to enhance military and political friendship and alliances with countries in the developing world including the Western Hemisphere. ${ }^{5}$ This way it has not only moved closer to like-minded governments but has enriched the options for joint military exercises and military training at a relatively low cost. In the last decade, Beijing has notably invested in the modernization of the People's Liberation Army (PLA), acquiring technological advancements that can be consequently offered to its allies. China's 'peaceful' military rise, however, has raised the alarm in small and middle countries in the Asia Pacific plus the likes of Australia and the United States. ${ }^{6}$ To some observers, China does not want to challenge the United States' dominance in world affairs. Beijing is said to seek cooperative relationships that would in return be beneficial for them. Nevertheless, Sino strategic culture based on peace despite differences seems highly reactive. If other actors pursue policies of intimidation through advanced military weapons, some observers argue that China will then react. ${ }^{7}$

The article takes such a scenario into consideration and presents the fo- 
llowing discussion. It surveys China's weapons transfer governance as part of its foreign policy and considers how such policies reflect on global norms of peace and cooperation. By studying the impact on Sino arms sales, we can further understand China's policy of reform and opening up to the world and what role diplomacy military policy has in these developments. The first section sets out an initial discussion on Chinese policy towards arms transfer and the pillars of Sino weapons diplomacy. The second section surveys how China's weapons diplomacy has reached the Western Hemisphere. This section explores Beijing's arms transfer to other zones of the world in conflict or peace situation, comparing these with the particularities of Latin America and the Caribbean. Section four then discusses how weapons have become a national and international concern when addressing traditional and non-traditional threats to security. The concluding section discusses what China's arms transfer means for understanding global arms governance, as well as the inroads of the Eastern superpower in the Western Hemisphere and the developing world in particular.

\section{Arms sales and international security}

Arms sales have a great saliency in foreign relations and international security. A particular sale might represent a major step in the quantity or quality of weapons being supplied to a particular buyer, which consequently causes suspicion among its adversaries. Everyday diplomacy in the twenty-first century deals with many sensitive issues, such as arms sales, through a culture of secrecy, silent power moves, and little transparency. ${ }^{8}$ In theory, arms diplomacy is the relation between weapons (and other forms of security) buyers and sellers from different states, these usually have larger political, economic and social consequences than the mere transactions of lethal or non-lethal military goods. ${ }^{9}$ Such arms diplomacy can happen either in the case of formal or informal diplomatic ties. Andrew Feinstein and Paul Holden coined a typography of the arms trade including activities ranging from government-to-government contracts, to arms trafficking involving non-state actors. ${ }^{10}$ It is not only arms dealers backed by governmental agencies who are usually frequent corrupt practices, but also arms sales in the grey market, which can be part of intelligence operations, where, for 
instance, one state can distribute weapons to embargoed parties (i.e. the Iran-Contra scandal). Black markets, they add, are arms transactions of an illegal nature and undertaken by dealers outside international conventions through various forms of trafficking that are punished with prosecution by law.

What distinguishes legal arms sales is that the supply and demand side of the equation responds to practices and actions that incorporate both economic and political transactions. Dave Kinsella and Alex Montgomery argue that the government-to-government transfer of small arms and light weapons (SALW), major conventional weapons (MCW), and weapons of mass destruction (WMD) 'are often elements in an ongoing politicalmilitary relationship between governments'. ${ }^{11}$ States con rely on formal military alliances to support arms sales between them. On the suppliers' side, a mixture of political, economic and global governance norms need to be taken into consideration, especially if such a country is participant to, for example, the ATT, which entered into force in late 2014. Functional reasons drive the demand side, such as particular security strategies, while political reasons that include seeking prestige, power and other symbolical attitudes such as sending status messages to internal or external audiences, are also involved. ${ }^{12}$ Light and major conventional arms are said to be an important currency in world politics ${ }^{13}$

For decades, states have chosen from a broad catalogue of arms suppliers offering SALWs and MCWs, with arms control and its trade only becoming a standardized norm after some of the advanced democracies agreed to the ATT chapters on transparency, accountability, international cooperation and monitor compliance. ${ }^{14}$ While advanced and middle nations have ratified and signed the treaty, the United States is only a signatory member who has not yet ratified it. Meanwhile, China and Russia formed part of the twenty-three abstentions that included other arms traders like India, Qatar and Saudi Arabia, which, according to reports, had been supplying weapons to armed opposition groups in Syria. ${ }^{15}$ Among the world's top ten arms producers, the United Kingdom, France, Germany, Italy, and Spain have ratified this through their congresses. China has showed support to regulate the international arms trade and combat the illicit transfer and trafficking of arms. ${ }^{16}$ 
Arms control and disarmament are double-edged concepts. Most states want to live in peace although also wanting to secure their sovereignty through the means of well-provisioned armed forces and security services. Weapons control treaties have prevented arms races, but states continue to invest in armaments as they are distrustful of other states and violent non-state actors. Arms control plays a big part in confidence building, and diplomatic negotiations are regularly attended by most states, including the most powerful. ${ }^{17}$ Nevertheless, states can avoid international norms. Israel, for example, has sold weapons through back-channel diplomacy to Arab, African and Latin American countries in order to improve foreign policy objectives. Although Sino-Israel relations were normalized in 1992, arms dealings are said to have occurred clandestinely since the early 1970s. ${ }^{18}$ The United States and other Western nations have done the same providing arms to Iran, Saudi Arabia and Israel, with the Soviet Union being linked to Syria, Iraq, Libya, and, Egypt. Both Cold War superpowers sent shipments elsewhere to Africa, Asia and Latin America. The influx of technologies plus more economic competitiveness has allowed nations such as Israel, South Africa, Taiwan, South Korea and India to begin their own armament industries. Through licensing agreements, developing countries can replicate technologies domestically. Defense offset manufacturing can provide opportunities for boosting local military industries. ${ }^{19}$

Arms sales are usually attached to some degree of controversy. In the 1980s, the United States sought to sell F-15s and F-16s fighters to Saudi Arabia, Pakistan and Venezuela, and other military supplies to Argentina, Guatemala and Chile. Congress and various other pressure groups put up a fight against President Ronald Reagan, arguing that the United States could not sell weapons to non-democratic, corrupt, or repressive governments. ${ }^{20}$ Perceptions of threat to their security fueled third world countries to their weapons self-sufficiency, while other countries used weapons acquisitions and manufacturing to improve their power status regionally (i.e. Argentina, Brazil, Venezuela and Indonesia). Despite these efforts, however, before the end of the twentieth century, no Third World country was able to develop an industry to challenge the United States, Russia, France or Great Britain.

It was only after the end of the Cold War -and with the changes that emerged in the international security regime- that China gradually edged 
into picture, redrawing the global arms sales economy. ${ }^{21}$ Beijing pushed its way into global arms transfer as its military capabilities proved able to challenge the balance of power in East Asia. ${ }^{22}$ Initially, China did not mean to be a direct challenge to the world's top arms manufacturers. However, the growing market presence of Beijing-made armaments were seen by many as part of its global grand strategy. In hindsight, China has followed a path that the rest of the advanced nations had followed previously. Washington, Moscow, London and Paris consolidated their arms sales policies as part of the array of their diplomatic means which had grown extensively since the early twentieth century. By the turn of the twenty first century, China swapped its disinterest in global arms manufacturing and control regimes to become a part of it. ${ }^{23}$ In developing countries this was more evident, as China materialized its arms transfers hand-in-hand with commercial and trade ventures.

\section{The Implications of Weapons Transfer}

Arms transfer is a multifaceted phenomenon on account of a number of issues. Transfers can have a positive or negative impact on regional stability depending on how this new arsenal is used and the reaction it generates in other regional actors. Arms sales also depict a relationship between buyer and seller, one which is fully charged with political signals. Weapons transfer can be about simple and minimal transactions or be large and have serious dependence implications for who is buying. ${ }^{24}$ For example, in 2015, president Barack Obama committed to Middle East leaders through the provision of military assistance worth billions in arms deals. In this way the Gulf Cooperation Council received military items including fighter aircraft, attack helicopters, radar planes, refueling aircraft, air-to-air missiles, armored vehicles, artillery, small arms and ammunition, cluster bombs, and missile systems. ${ }^{25}$

More recently, the Donald Trump administration is said to be pushing for a plan 'that calls for U.S. military attaches and diplomats to help drum up billions of dollars more in business overseas for the U.S. weapons 
industry, going beyond the limited assistance they currently provide' ${ }^{26}$ President Trump came to office with a strong agenda on expediting arms transfer processes to U.S. allies and partners. Washington recently released the Conventional Arms Transfer (CAT) policy and the Unmanned Aerial Systems (UAS) export policy to allow private U.S. defense companies to sell conventional weapons and unmanned drones directly, without having to go through the US government. ${ }^{27}$ In Europe, the British government has been criticized for its weapons diplomacy in relation to regimes in the Middle East where exported weapons can be used for repression and or against non-military targets. In most of these cases, arms sales require the balancing of many interests both across public and private actors.

Defense contractors have secured their way into arms deliveries in many regions, thanks to politicians. What is certain is that commercial, security and political interests are thornily embedded in what observers currently refer to as defense diplomacy. Studying the implications of arms sales thus requires not only an understanding of the figures and numbers behind a series of deliveries a seller makes to a buyer; rather, it demands new ways to identify more pressing implications for security and political statecraft.

Recent Arms Trade Trends

The volume of international sales of major weapons between 2013 and 2017 was 10 per cent higher than in the previous five years, according to the Stockholm Peace Research Institute (SIPRI). In that period, at least 67 countries were identified as exporters of weapons. The five largest suppliers were the United States, Russia, France, Germany and China, accounting for 74 per cent of all arms exports. The four year period reveals a few tendencies: (i) the flow of arms increased to Asia, Oceania, and the Middle East between 2008-12 and 2013-17, (ii) there was a decrease in arms going to Africa, the Americas and Europe, (iii) the United States accounted for 34 per cent of all arms exports, (iv) China was the fifth largest arms exporter, its exports rising by 38 per cent between $2008-12$ and $2013-17 .{ }^{28}$

According to the volume of international transfers of major weapons between 2013 and 2017, China accounts for 5.7 per cent of the world's share 
of arms exports. Beijing's growing ratio and its 8.1 per cent increase in military spending has Washington calling for ways to deter China's growing influence and military prowess, especially in regions of the world which are receivers of Sino arms. ${ }^{29}$ For developing countries, Chinese arms deals have also mostly meant new ways of restructuring their security stances in light of U.S.-Sino rivalry.

For China, a growing number of non-traditional security issues around the globe have become worthy of attention (i.e. weapons of mass destruction, global warming, transnational crime, drug trafficking, environmental pollution, financial security, communicable disease, and so on). It is the hope of the Chinese authorities that by working together with Beijing, arms recipient nations, such as those in the Western Hemisphere and other developing regions, can help provide their own security, thus cascading beneficial outcomes for global security.

\section{China's Arms Transfer Governance}

Where does China's policy stands in relation to global arms transfer governance and international security? Chinese statecraft for the issue of arms transfer has grown over the last decade, and under strict central control. At the heart of the recently restructured Ministry of Foreign Affairs rests the Department of Arms Control. The remit of this middle-ranked office rests on four major tasks that interlink with other state offices supporting Sino arms policy both for domestic and foreign security purposes. The department in is charge of:

1. Reporting on issues such as international arms control, disarmament, non-proliferation, export control and global and regional security;

2. organizing the development of relevant policies, working with other departments to manage related cases and organizing negotiations on relevant international treaties and agreements;

3. cooperating with other departments for compliance of international 
treaties and agreements;

4. and, finally, guiding China's overseas diplomatic missions on relevant issues.

The arms control department steers China's policy on thematic areas that include general security and arms control issues, non-proliferation issues, nuclear issues, chemical and biological weapons, outer space and missile issues, and conventional arms control. Since the Cold War era, for each of these complex subjects, China has gradually joined, either as a signatory or as an observer, a series of international treaties. ${ }^{30}$ The Chinese authorities have set out the governance of arms transfer in light of these three main guidelines:

1. Exports should be conducive to the legitimate self-defense capability of the recipient country;

2. exports should not undermine the peace, security and stability of the region concerned and the world as a whole;

3. and, exports should not be used as a means of interfering in the internal affairs of the recipient country.

The Chinese government has sought to blaze a trail of prudent politics towards who is able to buy from them. Most notably, these need to be sovereign states that cannot re-sell the exported arms to a third party without consent from the Chinese authorities. Additionally, China refused to sell arms to countries or regions under the arms embargo imposed by the UN Security Council and declared a policy of not transferring arms to non-state actors or individuals. ${ }^{31}$

China has shown a willingness to both study and take active part in relevant working groups such as the UN Group of Governmental Experts (GGE), the Open-ended Working Group (OEWG), the ATT Diplomatic Conference. Beijing also contributes to the UN Register of Conventional Arms which reports on imports and exports of major weapons systems. The register provides a certain degree of transparency on the global arms trade scene and presents a systematic categorization of weapons systems 
under seven categories. According to the register, China has exported weapons to over 30 countries, mostly in South America, Africa, Middle East, and South East Asia. ${ }^{32}$ This data confirms other estimations done by independent think tanks (i.e. SIPRI's Arms Transfers Database), and by Western governments (i.e. the U.S. World Military Expenditures and Arms Transfers, or WMEAT). Sino arms export policy also contemplates efforts to combat the illicit trade in small arms and light weapons. Although, because China sells to many places where conflict is active (i.e. Yemen, Sierra Leone, Sudan, among others), it is difficult to fully ensure if illicit trade counter-efforts are fully respected. The UN has implemented a multilateral approach to work with governments in ensuring the success of combating illicit weapons trade; however, multiregional efforts have been thwarted by uneven regional instabilities and lesser development in many parts of the developing world where black markets fuel dark economies.

Finally, China is an observer of the Ottawa Convention that prohibits the use, stockpiling, production and transfer of anti-personnel mines. When the convention was declared in 1998, neither Beijing nor Washington agreed to sign the accord. By the time China argued that all states had a right to use mines to fight foreign aggressors, Beijing was by then the world's biggest manufacturer of landmines. What has changed since is that a growing number of countries have extended or reconfirmed their moratoria on exports of antipersonnel mines, including, Israel, Poland, Russia, Singapore, South Korea, and Turkey. Since the early 2000s, both Washington and Beijing have significantly increased their contributions to international mine action programs. ${ }^{33}$

China's Defense Expenditure

In early 2018, at China's 13th National People's Congress (NPC) in Beijing, a major military spending boost unfolded, giving an annual increase of 8.1 per cent to drive the modernization of its armed forces. Beijing expected to spend US $\$ 175$ billion across all branches of the PLA, with China's military budget reflecting Xi Jinping's desire to augment the sophistication and reach of its military complex. Zhang Yesui, a then-spokesman for the NPC, explained that China's defense budget is so 
large to make up for low military spending in the past and is mainly used to upgrade equipment and improve the welfare of its troops. ${ }^{34}$

Worldwide, the United States leads the race on military spending with a budget of US $\$ 686$ billion, followed by China, and then Russia, with about a ninth of what Washington spends in its arsenal. In terms of arms trade, the United States also leads the way, followed by Russia and then China. ${ }^{35}$. Since 2010, China has bolstered a 'coordinated development' policy between the national defense and the economy. On different white papers and governmental documents, the Department of Arms Control has utilized a concept to inform the world that China is on a path of 'peaceful development' and has a 'defense policy which is purely defensive in nature'. ${ }^{36}$ This includes the elaboration of a military program that 'it is not directed to any specific country', and aims to provide a 'prosperous society'. ${ }^{37}$ At least on paper, the Sino defense policy builds on assurances of trust, cooperation, stability and development with the international regime. ${ }^{38}$ In order to pursue a 'coordinated development' policy, Beijing's national defense budget uses around two per cent of the overall fiscal budget, compared to over three per cent in the United States, five per cent in Russia, and ten per cent in Saudi Arabia.

China also evidences a network of state-owned weapons companies that trade in the domestic financial stock markets. Chinese military contractors have spawned when a wave of military privatization hit the country. ${ }^{39}$ By 2012, China counted at least 1,000 state-owned military enterprises. Among these were leading contractors such as the China State Shipbuilding Corporation (CSSC), Aviation Industry Corporation of China (AVIC) and China Aerospace Science and Industry Corporation. AVIC aimed to quadruple its sales to US 157.7 billion by 2020. Reports have accounted for China's top 10 defense groups listed with more than 70 subsidiaries, including over 40 with defense-related businesses. ${ }^{40}$ Since 2017, China's modernization drive plus strict steering from central government has allowed for China's military complex to launch its first domestic-made aircraft carrier, a guided-missile destroyer, open a military base in Djibouti, send warships through the Mediterranean and into the Baltic Sea, try out its newest stealth fighter, the J-20, and announce the debut of the Dongfeng-41 intercontinental ballistic missile. Building up its domestic 
military is allowing China to both deter potential enemies in Asia and elsewhere, while giving Beijing the chance to push its arms sales onto client states. Although the global market share of China is still minor compared to the United States, Europe, and Russia, the modernization of its armory is notable and a key segment of its weapons diplomacy.

\section{Weapons Diplomacy: Beijing and Washington}

Former presidents, Jiang Zemin and $\mathrm{Hu}$ Jintao, restructured Chinese governance to boost national industry, including the military industry, as an extension of their grand strategy to counter Western dominance in the world's political economy. ${ }^{41}$ By the mid-1970, China's main buyers of arms were North Korea and Vietnam. At the turn of the century the list had expanded greatly to places where Sino interest was rapidly consolidating, including South East and South Asia, North Africa, and Latin America. China's evidenced economic and technological modernization evidenced gave the PLA a broad array of strategic options to follow in the technological military industry. As noted by some observers, 'defense-industrial self-reliance is regarded as indispensable to China's security'. ${ }^{42}$ This has served a twofold endeavor. First, it has attracted foreign capital to China; and second, it has allowed for resource allocation to the indigenous military complex. The relationship between the PLA and civilian authorities has not turned out so easy. In Beijing, a growing list of domestic issues worry the civilian elites as they need to draw resources into their banking, health, housing, and construction sectors, plus deal with the many reforms proposed to transform state-owned corporations. ${ }^{43}$

Military affairs in China, and the weapons industry by default, have grown in balance to what the PLA can arguably demand and what the Chinese Communist Party (CCP) can offer in return. Military capabilities and the modernization of Sino geo-strategic capabilities in ground, aerospace, and maritime arsenals are said to shed light on the gradual accommodation of influence between the two most powerful institutions in China: its military and the party. Scholars argue that once the PLA reaches a degree of corporate autonomy, advancing the professionalization of its forces, their unconditional loyalty to the ruling Party may weaken. 
The resulting shift of balance between the two will not only affect China's own political development but also impact how China unfolds its weapons diplomacy on the world stage. ${ }^{44}$

Between 2013 and 2017, China exported weapons to 48 countries around the globe. In Africa, China's arms sales record shows a collective purchase of around 21 per cent of China's overall arms exports since 2008. In Asia, the main Sino arms buyers include Pakistan, Bangladesh and Myanmar. North African countries, such as Algeria and Morocco, are the primary destination of Chinese weapons, with other Sub Saharan countries equally eager to buy from them, such as Tanzania, Nigeria, and Sudan. ${ }^{45}$

A different story was told in the early 2000s when the United States dominated the world arms market and China was a minor actor. In the fiscal year 2000, at least 154 countries got contracts or deliveries with North American arms companies. The Clinton administration reverted what was the U.S. arms policy export rule to protect national security interests and limit conventional arms proliferation. In contrast, Washington engaged in a strongly-oriented commercial policy, with weapons sales and production becoming highly globalized. The post-Cold War scenario however turned difficult for suppliers as an excess of arms arsenals and a reduced demand in sales made the 'global arms bazaar highly competitive'. ${ }^{46}$ Washington's arms policy also entered into conflict. Exports were highly-driven by profits made in conflict areas or from deliveries made to repressive governments, that in turn kindled severe abuses. Rather than scrutinizing the weapons regime, President Clinton loosened export restrictions. Consequently, discussions to reform arms exports policy did not secure more control over conventional arms proliferation.

John Caverley and Ethan Kapstein wonder when Washington 'squandered' its monopoly on weapons sales. ${ }^{47}$ In the 1990s the United States controlled 60 per cent of the global weapons market, while in 2012 it was only about 30 per cent. Both authors argue that Washington focused on developing expensive and cutting-edge weaponry systems, leaving space for competitors to supply markets in developing parts of the global that seek more affordable options. In this way, Russia, China, Israel, and South Korea grasped niche markets with their own weapon industries. Arms transfers have a geopolitical dimension that tends to benefit seller states. 
However, a consequence of the United States retrenching from the globe is that somehow its influence over security decisions elsewhere has also become diminished. Washington, as well as Russia and China, can arm their allies and compete with each other through proxy recipients of weaponry. Washington does so in the Asia Pacific to diminish China, and in Europe to restrain Russia. The arms embargo put on China in 1989 partially enclosed China in order to access a smaller share of the world arms market. Since then China has sought alternatives routes. For instance, today it is the largest supplier of arms to Pakistan which is less interested in what Western high-tech weaponry can offer, and more into medium-sized affordable arms. $^{48}$

Chris Parker argues that much of the international arms trade is still dominated by the United States because of its ability to dictate cutting-edge technology standards. ${ }^{49}$ In fact, when countries decide to acquire weapons systems from a competitor state, for example, Russia, the risk of falling behind in technological assistance is greater, plus there is no guarantee that the domestic technological capabilities of buyers will endure the maintenance of highly advanced systems. For instance, China started a licensing agreement with Russia in the late 1990s in order to purchase Su-27s fighter aircrafts, however, the Sino military industrial complex hardly benefited from short-term technological diffusion. It was almost a decade later that the Chinese fighter J-11, and its indigenously-produced variants based on $\mathrm{Su}-27$, made its operational debut.

Despite serious efforts in technological advancement, China remains to this day in the second tier of arms producers. The top five largest exporters of major arms in 2013-2017 were the United States (with 34 per cent of the global share), followed by Russia (22 per cent), France (6.7 per cent), Germany (5.8 per cent), and China (5.7 per cent). China plays a dual-role in the arms trade as it is also the second main client of France and Germany. Only Brazil is worth mentioning as a Latin American arms producer, exporting 0.2 per cent of the global share, similar to the performance of South Africa, Finland and Portugal. ${ }^{50}$

On the other hand, China ranks fifth in the list of largest importers of arms with 4 per cent of the global share, behind India (12 per cent), Saudi Arabia (10 per cent) Egypt (4.5 per cent) the UAE (4.4 per cent). 
Latin American major importers, however, have a smaller participation in the market, with Venezuela (1.1 per cent of the global share), Mexico (0.7 per cent) and Brazil (0.6 per cent), whose suppliers include the United States, France and Russia. Nevertheless, Beijing's long-term investments in its military industry have facilitated the global diffusion of arms deals. Between 2008 and 2017, spending in China increased from 5.8 per cent to 13 per cent of the world's military expenditure. Asia and Oceania comprise the second region with the most military spending (US\$ 477 billion in 2017), following the Americas (US\$ 695 billion), where the United States and Canada alone take 91 per cent of the continent's expenditure.

Although fiscal budgets for military capabilities have diminished in the Americas (in 2016 it was 11 per cent lower than in 2008), Central America, expenditure of the Caribbean and South America has evidenced ups and downs across the last decade. ${ }^{51}$ In part due to the receding economic climate, Latin America remains a conundrum for China. The region represents a smaller fraction of Beijing's world arms sales. In 2013-17 Asia and Oceania accounted for 72 per cent of Chinese arms exports, Africa for 21 per cent, the Americas for 4.9 per cent and the Middle East for 2 per cent. China is well behind the major arms sellers in the Western Hemisphere. The major imports come from South American states that in 2013-17 took 43 per cent of transfers in the Americas. Russia accounted for 27 per cent of deliveries to South America, followed by the United States (15 per cent) and France (9.8 per cent). By 2008, China had delivered US $\$ 41$ million, however, in 2015, the amount increased to US\$ 178 million. In 2016, sales topped at US\$ 36 million. Meanwhile, the think tank SIPRI did not record any sales in 2017.

The pitfalls of Chinese weapon diplomacy in Latin America are also linked to Beijing' own industry limitations. The lack of cutting-edge research and development $(\mathrm{R} \& \mathrm{D})$ for military technological capability, plus a global market share owned by Washington and Moscow, inhibits the Sino defense industry from making considerable growth. ${ }^{52}$ For China's plans in Latin America this issue presents at least two obstacles. Sino weapons diplomacy fits best with states that represent a higher military purchase capacity in geographical areas of potential conflict. Latin America has roughly higher per capita GDP compared to Africa, the Middle East, 
and parts of Asia, however, the absence of interstate tension has partially undermined governments' capacity to expand on arms purchases.

\section{Western Hemisphere's Security Scenario}

The latest active conflict registered in the Americas was fought between Peru and Ecuador in 1995 over control of a border area in the Upper Cenepa valley. Since then, most conflict in the region has remained of intrastate character, for example, Colombia and Peru fighting internal guerrillas, namely the FARC and the Shining Path, respectively. The 1990s was meant to be a decade of learning from the mistakes of previous world conflict, especially when it came to curb the flow of arms to violent regions. However, when leadership from advanced nations was needed, governments in industrialized countries decided to sustain a strategic arms transfer to developing countries, including Latin America. By 1991, the United States had supplied 57 per cent of all arms sales to the Third World. At least since the 1970s, arms transfers had been a key priority for Washington, with military strategists, industry lobbyists, and government officials believing that arms would keep allies satisfied in volatile regions with the most anti-American feelings.

Since the presidency of Jimmy Carter, the United States has had a record of using its arms transfer policy as a bargaining chip to win access to military bases in Africa, Asia, the Middle East and Latin America. Also, arms transfer had been used as an icebreaker and dealmaker in key U.S. foreign policy initiatives. Military technology transfers and military aid can be used as diplomatic carrots from a supplier state to obtain other valued objectives. Nevertheless, these policies did not always incorporate how to counter regional arms races that would fuel future conflict. As William D. Hartung puts it, the United States had 'no serious rival for the dubious honor of serving as the world's number-one arms dealer'. ${ }^{53}$ Chinese arms sales to the Third World, on the other hand, accounted for less than one-fortieth the level of U.S. exports. Beijing became considered a 'rogue proliferator' for its sales of missile and nuclear technology to regimes in the Middle East and South Asia. 
South American arms imports grew from US\$ 472 million in 1994 to 1.3 billion in 1995 making it the fourth largest importing region in the world with a four per cent share of the global market. The jump was attributed to big increases in purchases from Chile (US\$ 267 million), Peru (US\$ 218 million), Ecuador (US\$ 209 million), and Brazil (US\$ 67 million). Regional imports grew in the period 1991-1995 to seven per cent. Ecuador (72 per cent), Chile (42 per cent), Argentina (29 per cent), and Peru (29 per cent) had the highest growth during the period. As well, Chile (US\$ 525 million), Brazil (US\$ 430 million), Peru (US\$ 375 million), and Ecuador (US\$ 370 million), were the most relevant arms importers between 1993 and 1995. ${ }^{54}$ By then, Beijing's weapons diplomacy had already touched land. According to data from the SIPRI think tank, Bolivia acquired over 50 towed guns, D-20 and M-30, delivered between 1992 and 1993. Another 30 portable air-defense systems (SAM) were delivered in 1995. Ecuador received 72 HN-5A type portable SAMs and launchers, and 50 Red Arrow- 8 anti-tank missiles in 1994. Peru, another buyer, received a delivery of six Harbin Y-12 light military transport aircraft. ${ }^{55}$ The $\mathrm{Y}-12$ planes were used by Peru to fly reinforcements to the Upper Cenepa Valley. Both countries used their imported weaponry in, among other key battles, the fight over the Tiwinza Ecuadorian military post on 28 January.

Despite both parties signing a peace process in Montevideo, Uruguay, in February, confidence was lost and military build-up increased. Peru increased its defense budget during 1993-1997 by an average of over 10 percent, along with the likes of Mexico, Brazil and Colombia; a trend replicated outside the region by Angola, Armenia, Indonesia, Libya, Namibia, Singapore, Uganda, and Vietnam. In the 1995-1997 period, South America became the fifth largest importing region in the world, with Brazil (over US\$ 1 billion), followed by Peru, Chile, Venezuela, and Ecuador as the main weapons buyers. ${ }^{56}$ In 1998, Peru and Ecuador agreed to sign a peace treaty that would tackle the main areas of contention between the countries: demarcation of the border, trade and navigation, and security and confidence-building measures. Nonetheless, Peru's purchase of MiG-29 fighter jets and Sukhoi bombers, raised alarms among the guarantor nations. At the turn of the century, both Peru and Ecuador would turn largely to Sino arms. 
Potential hot spots of conflict remaining between distrusted states prompted governments to keep their war arsenal updated (i.e. Chile, Bolivia and Peru; Colombia and Venezuela), although the region's cycle of instability has been somewhat controlled. ${ }^{57}$ In Venezuela, for example, the change in government to left-wing president Hugo Chávez meant a serious disruption between Caracas and old-time ally, Washington. Venezuela sought assistance from the East, namely Moscow and Beijing, and has since benefited from vast weapons deals paid with the revenue taken from state-owned corporations in the oil sector.

Since commodities depreciation hit the international market, most acquiring capabilities have wound down. Caracas is also wary of its neighbor Colombia, whose security links with the United States were consolidated following Washington's military aid to help fight drug traffickers, right-wing paramilitaries and left-wing insurgencies well since the 1960s. Since Colombia does not trade arms with China, Beijing can freely sell to Venezuela without raising any suspicion. This way, Beijing has snooped in major intrastate rivalries across the world, for example, selling arms to Pakistan, but not to India, which consequently relies heavily on U.S. weapons.

Such an argument drives us to entertain a further idea. China's arms diplomacy was thwarted in Latin America in light of a different presence of non-state armed actors, thus, driving regular armies to focus on ad-hoc missions and roles not necessarily requiring what China can sell. In contrast, in the Middle East, where Beijing is a sizeable arms supplier, there is a proliferation of selling orders for Chinese air-launched cruise missiles for potential use against ground targets, be this state or rebel forces. Pakistan recently bought ALCM from China and Qatar received ballistic missiles. So far, China has sold Latin America anti-tank missiles, trainer and transport aircraft, air search radars, and light artillery weapons. The growing trend toward human security in the Americas is driving the most capable armed forces towards less combat potential imports and more multi-tasking hybrid military technologies. ${ }^{58}$ Brazil, for instance, recently announced its purchase of the former Royal Navy helicopter carrier and assault ship HMS Ocean, plus an order of submarines from France and aircraft from Sweden, to be delivered by $2025{ }^{59}$ Brazilians are worried about the protection of natural resources and the overall territoriality of their country, one of the largest in 
the world.

Arms race in the region?

Arms races and military competition have been commented upon by many students of the Western Hemisphere, especially in light of the post-2000s boom in military spending. Observers have been wary of an "arms race" as many argue that the weapons buying trend responds to the modernization of old stockpiles and an effort to access new military technologies. ${ }^{60}$ The fact remains, however, that arms build-up raises questions as to whether a state's arms capacity can deter possible aggression from potential adversaries. In this vein, what tends to matter the most is how a state in conditioned by its own motives and the constraints and opportunities created by its security environment in light of variables, such as power balances among adversaries and the information they can hold about other states' motives for conflict. ${ }^{61}$

The most representative case is that between Colombia and Venezuela. Between 2009 and 2016, Venezuela acquired an air defense system and battle tanks from Russia, plus air-radars, anti-tank missiles and anti-ship missiles from China. Both countries have a record of skirmishes, including a deployment of troops from the side of Caracas after Bogota launched an air strike against the FARC guerrilla, overstepping territories in Ecuador. This event led to the so-called Andean crisis of 2008 in which all three countries armed their borders with tanks, troops and helicopters for a week, and a group of countries, including the conflicting parties, met in the Dominican Republic to call an end to the stand-off. Diplomatic tension between the two countries has remained and most recently, Bogota decided to send 2,000 extra troops to protect its border due to the recent socio-political crisis in Venezuela that has prompted a massive movement of migrants. Brazil replicated the measure sending its military to the border.

Economic and technological relations between the industrialized nations and the Third World is increasing the flow of conventional weapons. However, the political repercussions of a disarrayed arms regime in Latin America should be a matter of preoccupation for China and the main arms suppliers to the region. Armed violence, corrupt governments, and shady 
weapons industries in the region are a risky mix for any foreign actor dealing with Latin American buyers. What are the implications for Sino arms diplomacy given such a scenario? How does the so-called Latin America's "arms race" fit into Chinese arms sales? Possible answers to these questions unveil a myriad of underlying topics (i.e. the struggle for bureaucratic strengthening, under-development, and human rights violations) that make the Latin America's security regime a dangerous place for buying and selling arms.

\section{Hot spots of violence}

Although most observers would argue that China's arms sales concentrate in parts of the developing world which are home to several armed conflicts, the argument is equally applicable to the United States and Russia. Half of U.S. arms deals are to states in the Middle East, which according to the Council on Foreign Affairs is the most critical hot spot of conflict impacting Washington's interests. ${ }^{62}$ Russia, on the other hand, delivers most of its exports to India, China and Vietnam, and has also delivered arms to the rebels in Ukraine. Washington and Moscow sell in other conflict-ridden hot spots such as Iraq, Afghanistan, and Egypt. Made in the United States arsenals are sold in various contending places in East Asia, mostly to its security partners in South Korea, Japan, and most recently, Taiwan. In 2017, for example, the United States signed off its first major weapons delivery to Vietnam as part of its grand strategy in Asia and Oceania, a move that some observers argued would purposefully offset China's growing influence. ${ }^{63}$ The point to take from these developments is that the big weapons exporters have partnerships across the globe, no matter if the scenario is one of conflict or peace.

In the developing Western Hemisphere, the situation has followed a similar path. The subcontinent and the Caribbean basin are the most violent regions in the world, with an annual homicide rate of more than 20 per 100,000 population and with an increasing trend to violence in urban hot spots. ${ }^{64}$ Crises of violence in Mexico and Brazil, and more recently, Central America's spillover of criminality has governments spending increasing amounts on arming their military and police forces. The 
Mexican government received US\$ 150 million in funding to help set up more controls of its southern border to detain migrants from crossing. The problem is that while Donald Trump blocks the U.S-Mexico border, maybe thousands of migrants will get stuck on their way north. Migrants have had a rough time passing through Mexico, with at least 5,000 cases of migrant homicide in 2016. ${ }^{65}$ One of the last attempts made by Barack Obama, was to launch the Alliance for Prosperity in the Northern Triangle, together with El Salvador, Guatemala and Honduras, and totaling US\$1.4 billion dollar in aid for political stability and economic growth. The plan aimed to support security and governance initiatives as well as stop the economic drivers of illegal immigration and illicit trafficking. ${ }^{66}$

In the recent wave of bloodshed hitting Central America, 77 per cent of all murders were committed with a firearm. ${ }^{67}$ The three civil wars that tainted the central region (Guatemala, 1960-1996; El Salvador, 1980-1992; and, Nicaragua, 1972-1991) left the armories at the disposal of violent non-state groups once the regular armies were downsized under the peace accords. Most of the handguns and military-grade weapons were made in the United States and other allies during the Cold War. Nevertheless, the United States' diminishing role in the Americas and subsequent vacuum has offered Asian players a gap to fill. In January 2017, the Taiwanese President Tsai Ing-wen visited Central America and signed major trade and arms deals. ${ }^{68}$ Unlike many parts of the world, Central America recognizes the sovereignty of Taiwan despite the pressure imposed by China upon those who refuse to consider it a breakaway region, as Beijing does. Guatemala, Belize, El Salvador, Honduras, Nicaragua and Paraguay remain stubborn allies with Taipei. Surprisingly, the Dominican Republic swapped sides in favor of Beijing, despite the fact that Taiwan donated the Dominican armed forces two Bell UH-1H helicopters, 90 AM General Humvees, and 100 engines valued at more than US\$35 million. ${ }^{69}$ Taipei military donations had also previously backfired. In the early 2000s, a large donation of assault rifles was lost in the hands of insurgents in Nicaragua and Haiti. ${ }^{70}$

China has avoided funneling bigger arms deliveries to Central American hot spots. As it did in North Africa, Beijing began to build stronger links with states able to provide it with a formal platform for military aid and alliances. In South America, China's current development under its arms 
diplomacy has allowed Beijing to gain spaces in conflicted and peaceful zones of the globe, similar to how the United States did before. In Bolivia, for example, Washington landed political and security aid programs with liked-minded governments in La Paz from the 1990s. President Evo Morales, on the other hand, came to power with an anti-imperialist agenda and gradually cut off ties with Washington, finally expelling the U.S. Agency for International Development in 2013. By then, China had already arrived in Bolivia, mostly with military transport vehicles donated in various stages from 2007 to 2010. Once the United States left the Andean country, Beijing kickstarted a more serious arms transfer, for example, selling six Panther helicopters in 2014 and donating 27 Tiger light armored vehicles in 2016. In contrast to Central American countries, Bolivia is a relatively safe country and has not experienced armed conflict since the Chaco War was fought against Paraguay in the 1930s. After that, government defeated the alliance of Cuban and Bolivian guerrillas led by the Marxist revolutionary Ernesto "Che" Guevara in the mid-1960s. Since then, most military efforts have been put to alternate military missions to counter drug trafficking in the Andes. Bolivia and Peru, two of China's arms clients in the region, are the world's main producers of coca leaves.

\section{Conclusion}

At the outset of this article, I posited the question what characterizes China's arms transfer diplomacy and how does it play out in the context of a developing region? Beijing's recent military and diplomatic shake up revealed Xi Jinping's desire to expand its global influence. Arms dealing is at the center of such priority, and military, civil and private authorities are part of such a doctrine in this era of globalization. It can be argued that China's arms transfers to some parts of the developing world are characterized by a strong desire to reinforce multilateral disarmament treaties, however, in practice, Beijing is pushing for a more aggressive strategy to maximize its stake of the world arms market. ${ }^{71}$ In March 2015, Foreign Ministry spokesperson Hong Lei' was asked the following at a press conference: 
The Stockholm International Peace Research Institute issued a report today, saying that China has become the third largest arms exporter. Some experts share the view that China's arms export has increased in recent years because China does business with regions that some western countries are unwilling to do business with. What is China's response to this?

Hong replied:

Rankings in this field change every year, and opinions from various institutions differ from each other. On arms export, China takes a prudent and responsible attitude and conducts strict management in accordance with domestic laws and regulations while complying with the UN Security Council resolutions and other international obligations. China follows the principle of contributing to the recipient country's capability of justified self-defense, not undermining international and regional peace and stability, and not interfering in the domestic affairs of the recipient country. ${ }^{72}$

The paradox is quite obvious as many developed and developing states pledge allegiance to UN's regional disarmament process and to counter the abuse of conventional arms. However, the expansion of China's domestic weapons industry is of equal notoriousness. The top sellers of armament actively participate in illicit arms trade prevention programs, tailor their domestic legislation, empower law enforcement, and push for international cooperation. But there is no treaty that can challenge a country's national defense industry requirements to grow bigger and more powerful. Many weapons produced by the major exporters are difficult to regulate, most notably SALW, which currently constitute a major problem in hot spots of conflict, such as in Latin America, Africa, the Middle East and Asia.

In light of today's traditional and non-traditional security challenges across the globe, the pillars of Sino arms diplomacy are not easily enforceable. ${ }^{73}$ The capabilities that China has for deterring a buyer country from passing imported arms to a third recipient are scarce. Of course, Beijing could prevent further selling weapons to a state not complying with such a rule. However, arms records can be erased and SALW can easily find the black market and be resold. Also, securing that Chinese-made arms 
will not enter embargo zones seems equally difficult or implausible. China has opposed previous UN arms embargos, arguing they do not help to solve underlying problems. Finally, deterring Chinese arms from making it to non-state actors or individuals in regions such as Latin America, Africa, or the Middle East, seems equally hard to do. One must query if China's arms trade regulations are feasible in the real world and what the implications are for buyers around the globe.

Arguably, it seems that China's dual tracks for approaching international security has them seeking both validation and active participation in the arms control global regime. In May 2016, Chinese vice Foreign Minister Li Baodong and U.S. Under Secretary of State for Arms Control and International Security Rose Gottemoeller exchanged views on current international security, global nuclear governance, outer space security, missile defense, non-proliferation, arms and military cooperation mechanisms. The meeting included representatives of relevant departments, including the Ministry of Foreign Affairs, Ministry of National Defense and State Administration of Science, Technology and Industry for National Defense of China, as well as the Department of State, the White House National Security Council and the Department of Defense. ${ }^{74}$ The point to conclude here is that international security is being redrawn by the two most powerful countries in the world through a myriad of interested parties embedded in the military, civil, and diplomatic policy communities. Arms transfers and the outcomes for security in the Western Hemisphere and other parts of the developing world should thus be positioned as part of a complex security governance regime. Eastern and Western arms producers may wish for a global scenario where cooperation and mutual strategic trust are extremely relevant, however, today's arms transfer regime is rather shady and highly competitive. China's weapons diplomacy in the Western Hemisphere is highly mobile thanks to states willing to buy not just weaponry but to strengthen their unilateral development and advance their strategic position in the region. In light of the unfolding post-hegemony of the United States, it seems that sooner rather than later China will rethink ways to expand its weapons diplomacy and pursue more partners in this part of the globe. 


\section{Notes}

${ }^{1}$ Gerald Segal, 'China: Arms Transfer Policies and Practices'. Contemporary Security Policy, 15(2), 156-173; Ian Taylor and Zhengyu Wu, 'China's Arms Transfers to Africa and Political Violence', Terrorism and Political Violence, 25(3), 2013, 457-475; Zhifan Luo, 'Intrastate Dynamics in The Context of Hegemonic Decline: A Case Study of China's Arms Transfer Regime,' Journal of World-Systems Research, 23(1), 2017, 36-61; Ling Li and Ron Matthews, "Made in China": An Emerging Brand in The Global Arms Market',Defense Es Security Analysis, 3(2), 174-189.

${ }^{2}$ Stockholm International Peace Research Institute (SIPRI). 'World Military Spending in 2017 was $\$ 1.74$ Trillion', 2017, available at http://visuals.sipri.org (accessed January 2019).

${ }^{3}$ As the mass media put it recently, China seems to be taking advantage of a 'growing great-power vacuum in Latin America'. See The Economist. 'The Friendly Dragon', February 3, 2018, available at: https://www. economist.com/the-americas/2018/02/03/ china-moves-into-latin-america (accessed March 2019).

${ }^{4}$ Monica Herrera and Ron Matthews, 'Latin America in Step with Global Defence Offset Phenomenon', The RUSI Journal, 159 (6), 50-57.

${ }^{5} \mathrm{R}$. Evan Ellis, China on the Ground in Latin America (Basingstoke: PalgraveMacmillan, 2014); Georg Strüver, 'Bereft of Friends? China's Rise and Search for Political Partners in South America', The Chinese Journal of International Politics, 7(1), 2014, $117-151$.

${ }^{6}$ Pratnashree Basu and Rakhahari Chatterji, 'China's Race for Arms,' Jadavpur Journal of International Relations, 20(1), 2016, 1-32.

${ }^{7}$ Xia Liping, 'How China Thinks About National Security', in Ron Huisken (ed) Rising China: Power and Reassurance (Canberra: ANU Press, 2009), pp. 103-118.

${ }^{8}$ Andrew F. Cooper, 'The Changing Nature of Diplomacy', in Andrew F. Cooper, Jorge Heine, and Ramesh Thakur (eds) The Oxford Handbook of Modern Diplomacy (Oxford: Oxford University Press, 2016), pp. 36-50.

${ }^{9}$ The U.S. Disarmament and Arms Control Agency provides a definition of arms transfer worth introducing early on: 'Arms transfers (arms imports and exports) represent the international transfer (under terms of grant, credit, barter, or cash) of military equipment, usually referred to as "conventional," including weapons of war, parts thereof, ammunition, support equipment, and other commodities designed for military use.'

${ }^{10}$ Andrew Feinstein and Paul Holden, 'Arms Trafficking', in Letizia Paoli (ed) The $O x$ ford Handbook of Organized Crime, (Oxford: Oxford University Press, 2014), pp. 444-459.

${ }^{11}$ David Kinsella and Alexander H. Montgomery, 'Arms Supply and Proliferation Networks', in Jennifer Nicoll Victor, Alexander H. Montgomery, and Mark Lubell (eds) The Oxford Handbook of Political Networks (Oxford: Oxford University Press, 2017), pp. $761-786$.

${ }^{12}$ Kinsella and Montgomery, 'Arms Supply and Proliferation Networks'.

${ }^{13}$ Jennifer L. Erickson, Dangerous Trade: Arms Exports, Human Rights, And International Reputation (New York: Columbia University Press, 2015). 
${ }^{14}$ By 2018, ninety-one states had ratified the ATT and 130 had signed it.

${ }^{15}$ Colum Lynch. 'U.N. Passes Landmark Arms Trade Treaty; Some Major Powers Abstain,' Foreign Policy, April 2, 2013, available at https://foreignpolicy.com/2013/ 04/02/u-n-passes-landmark-arms-trade-treaty-some-major-powers-abstain/ (accessed January 2019).

${ }^{16}$ Foreign Ministry of the People's Republic of China (FMPRC). 'Arms Trade Treaty Initiative', April 7, 2011, available at http://www.fmprc.gov.cn/mfa_eng/wjb_663304/ zzjg_663340/jks_665232/kjlc_665236/cgjkwt_665248/t410759.shtml (accessed March 2019).

${ }^{17}$ Neil Cooper and David Mutimer, 'Arms Control for the 21st Century: Controlling the Means of Violence', Contemporary Security Policy, 32(1), 2011, 3-19.

${ }^{18}$ Alvite Singh Ningthoujam. 'Return Of Israel's Arms Sales Diplomacy', Jerusalem Post, June 24, 2013, available at: https://www.jpost.com/ (accessed March 2019).

${ }^{19}$ Herrera and Matthews, 'Latin America in Step with Global Defence Offset Phenomenon'.

${ }^{20}$ Andrew J. Pierre, 'Arms Sales: The New Diplomacy,' Foreign Affairs. December 1, 1981, available at https://www.foreignaffairs.com/articles/1981-12-01/armssales-new-diplomacy (accessed March 2019)

${ }^{21}$ Anna Stavrianakis, 'Controlling Weapons Circulation in a Postcolonial Militarised World', Review of International Studies, Online First, 2018, 1-20.

${ }^{22}$ Ganguly, Sumit, 'The Balance of Power in South Asia', in B.J.C. McKercher (ed) Handbook of Diplomacy and Statecraft (London: Routledge, 2012), pp. 398-404.

${ }^{23}$ Gary Klinsworth, 'China and Arms Control: A Learning Process,' The Journal of East Asian Affairs, 14(1), 2000, 84-116.

${ }^{24}$ David Kinsella, 'Arms Transfer Dependence and Foreign Policy Conflict', Journal of Peace Research, 35(1), 1998, 7-23.

${ }^{25}$ Williams D. Hartung. 'It's Not Diplomacy, It's an Arms Fair', Foreign Policy, May 14. 2015, available at: https://foreignpolicy.com/2015/05/14/obama-arms-faircamp-david-weapons-sales-gcc/(accessedMarch2019).

${ }^{26}$ Mike Stone and Matt Spetalnick. 'Exclusive: Trump To Call On Pentagon, Diplomats To Play Bigger Arms Sales Role-Sources', Reuters, January 8, 2018, available at: https: //www.reuters.com/article/us-usa-trump-weapons/exclusive-trump-to-call-onpentagon-diplomats-to-play-bigger-arms-sales-role-sources-idUSKBN1EXOWX (accessed May 2019).

${ }^{27}$ Zahary Cohen and Laura Koran. 'How Trump Plan to Arm The World With US Weapons', CNN, April 19, 2018, available at: https://edition.cnn.com/2018/04/19/ politics/trump-us-arms-sales-policy/index.html (accessed May 2019).

${ }^{28}$ World Economic Forum. 'What You Need To Know About Global Arms Sales In 6 Charts', March 14, 2018, available at: https ://www . wef orum .org/agenda/2018/03/whatyou-need-to-know-about-global-arms-sales-in-6-charts (accessed May 2019)

${ }^{29}$ Kristin Huang. 'China's Arms Sales Rise As It Vies With US For Influence On The World Stage', South China Morning Post, March 12, 2018, available at https://www.scmp.com/news/china/diplomacy-defence/article/2136877/chinas- 
arms-sales-rise-it-vies-us-influence-world-stage (accessed May 2019).

${ }^{30}$ Foreign Ministry of the People's Republic of China (FMPRC). 'List of Arms Control, Disarmament and Non-Proliferation Treaties That China Has Joined', 2014, available at https://www.fmprc.gov.cn/mfa_eng/wjb_663304/zzjg_663340/jks_665232/tyylb_ 665254/t141338.shtml (accessed May 2019).

${ }^{31}$ Foreign Ministry of the People's Republic of China (FMPRC). 'The Department of Arms Control', 2018, available at: https://www.fmprc.gov.cn/mfa_eng/wjb_663304/ zzjg_663340/jks_665232/ (accessed May 2019).

${ }^{32}$ United Nations. 'Global Reported Arms Trade Register: China,' 2013, available at: http://www . un-register.org/ (accessed March 2019).

${ }^{33}$ Human Rights Watch. 'Global Progress on Banning Landmines', September 9, 2003, available at https://www.hrw.org/news/2003/09/09/global-progress-banninglandmines (accessed May 2019).

${ }^{34}$ CNN. 'China Boosts Military Spending 8 per cent Amidst Ambitious Modernization Drive', March 4, 2018, available at: https://edition.cnn.com/2018/03/04/asia/ chinese-military-budget-intl/index.html (accessed March 2019).

${ }^{35}$ Center for Strategic and International Studies. 'What Does China Really Spend on its Military?', China Power Team, 2018, available at: https://chinapower.csis.org/ military-spending/ (accessed March 2019).

${ }^{36}$ Foreign Ministry of the People's Republic of China (FMPRC). 'China's Defense Expenditure,' April 7, 2011, available at http://www.fmprc.gov.cn/mfa_eng/wjb_ 663304/zzjg_663340/jks_665232/kjlc_665236/gjjk_665238/t410723.shtml (accessed March 2019). China's 'peaceful' foreign policy under president Xi Jinping has been the object of study of Eastern scholars and thoroughly covered, among other papers and monographs, in Jian Zhang, 'China's New Foreign Policy Under Xi Jinping: Towards "Peaceful Rise 2.0" ?, Global Change, Peace \& Security, 27 (1), 2015, 5-19; Weixing Hu, 'Xi Jinping's "Big Power Diplomacy" and China's Central National Security Commission (CNSC)', Journal of Contemporary China, 25(98), 2016, 163-177.

${ }^{37}$ The fundamentals of the Chinese defense policy go on to say: 'China pursues a road of peaceful development, and firmly pursues a national defense policy which is defensive in nature. China is a developing country with vast territory and large population. China's peace, security and development needs effective national defense. China's national defense is subject to and serves its development and security strategy. It is not directed against nor does it threaten any country, and its fundamental purpose is to safeguard national security and unity and ensure smooth progress of the cause of building a moderately prosperous society in an all-round way (... )'. See Foreign Ministry of the People's Republic of China (FMPRC). 'China's Defense Policy', May 27, 2010, available at http://www.fmprc.gov.cn/mfa_eng/wjb_663304/zzjg_663340/jks_665232/kjlc_ 665236/gjjk_665238/t410720.shtml (accessed March 2019).

${ }^{38}$ China's 2015 military policy addresses the international security regime with the following assessment: 'In today's world, the global trends toward multi-polarity and economic globalization are intensifying, and an information society is rapidly coming into being. Countries are increasingly bound together in a community of shared destiny. Peace, deve- 
lopment, cooperation and mutual benefit have become an irresistible tide of the times". Nevertheless, China sees the world with critical eyes especially the affairs of national unification, territorial integrity and development interests. See FMPRC, 'China's Defense Policy'.

${ }^{39}$ International Institute for Strategic Studies (IISS). 'Global Defence-Industry League: Where is China?' 2018, available at: https://www.iiss.org/blogs/military-balance/ 2018/08/china-global-defence-industry-league(accessed January 2019).

${ }^{40}$ Reuters. 'Insight: China builds its own Military-Industrial Complex,' September 16, 2012, available at: https://www.reuters.com/article/us-china-defence/insightchina-builds-its-own-military-industrial-complex-idUSBRE88F0GM20120916 (accessed May 2019).

${ }^{41}$ See Luo, 'Intrastate Dynamics in The Context of Hegemonic Decline'.

${ }^{42}$ Kenneth Boutin, 'Defence Technologies and Industrial Base', Richard A. Bitzinger and Nicu Popescu (eds) Defence Industries in Russia and China: Players and Strategies available at: https://www.iss.europa.eu/sites/default/files/EUISSFiles/Report_ 38_Defence-industries-in-Russia-and-China.pdf . (accessed May 2019).

${ }^{43}$ James C. Mulvenon et al. Chinese Responses to U.S. Military Transformation and Implications for the Department of Defense (Santa Monica, CA: RAND Corporation, 2016).

${ }^{44}$ You Ji, China's Military Transformation (Cambridge: Polity, 2015).

${ }^{45}$ Center for Strategic and International Studies. 'How Dominant is China in the Global Arms Trade?' China Power Team, 2018, available at: https://chinapower.csis.org/ china-global-arms-trade/ (accessed May 2019).

${ }^{46}$ Tamar Gabelnick and Anna Ric, 'Globalized Weaponry', Social Justice, 27(4), 37-44, p. 37.

${ }^{47}$ Jonathan Caverley and Ethan B. Kapstein, 'How Washington Squandered its Monopoly on Weapons Sales', Foreign Affairs, 91(5), 2012, 125-132.

${ }^{48}$ See Caverley and Kapstein, 'How Washington Squandered its Monopoly on Weapons Sales'.

${ }^{49}$ Christopher Parker, 'New Weapons for Old Problems: Conventional Proliferation and Military Effectiveness in Developing States', International Security, 23(4), 1999, 119-147.

${ }^{50}$ Stockholm International Peace Research Institute (SIPRI). 'Trends in International Arms Tranfers, 2017', 2018, available at: https://www.sipri.org/sites/default/files/ 2018-03/fssipri_at2017_0.pdf (accessed May 2019).

${ }^{51}$ See Sipri, 'World Military Spending in 2017 was $\$ 1.74$ Trillion'.

${ }^{52}$ Richard A. Bitzinger and Nicu Popescu, 'Introduction', in Richard A. Bitzinger and Nicu Popescu (eds) Defence Industries in Russia and China: Players and Strategies, available at https://www.iss .europa.eu/sites/default/files/EUISSFiles/ Report_38_Defence-industries-in-Russia-and-China.pdf (accessed May 2019).

${ }^{53}$ William D. Hartung, 'Retrospective: An Unstoppable Arms Trade?' World Policy Journal, 25(3), 2008, 61.

${ }^{54}$ See U.S. Disarmament and Control Agency, World Military Expenditures and Arms Transfers, 1996 (Washington, D.C.: United States Government Printing Office, 1997). 
${ }^{55}$ See SIPRI, 'Trends in International Arms Tranfers, 2017'.

${ }^{56}$ U.S. Disarmament and Arms Control Agency. World Military Expenditures Arms Transfers, 1998, (Washington, D.C.: United States Government Printing Office, 2000), pp. 5-9.

${ }^{57}$ David Mares, Latin America and the Illusion of Peace (Basingstoke: Routledge, 2012)

${ }^{58}$ Carlos Solar, 'Civil-military Relations and Human Security in a Post-dictatorship', Journal of Strategic Studies 42 (3-4), 2019, 507-531.

${ }^{59}$ See SIPRI, 'Trends in International Arms Tranfers, 2017'.

${ }^{60}$ Carla Solmirano and Sam Perlo-Freeman. 'Is South America on the Brink of an Arms Race?', 2009, available at: https://www.sipri.org/commentary/2009/jan-10-southamerica-brink-arms-race(accessed May 2009).

${ }^{61}$ Charles Glaser, 'When are Arms Races Dangerous: Rational Versus Suboptimal Arming', International Security, 28(4), 2004, 44-84.

${ }^{62}$ Council on Foreign Relations (CFR). 'Global Conflict Tracker', 2019, available at: https://www.cfr.org/ (accessed May 2019).

${ }^{63}$ See SIPRI, 'Trends in International Arms Tranfers, 2017'.

${ }^{64}$ Laura Jaitman and Nicolas Ajzenman. 'Crime Concentration and Hot Spot Dynamics in Latin America', Inter-American Development Bank, 2016, available at https: //publications.iadb.org/bitstream/handle/11319/7702/Crime-Concentrationand-Hot-Spot-Dynamics-in-Latin-America.pdf?sequence=1\&isAllowed=y (accessed May 2019).

${ }^{65}$ Shannon O'Neill. 'Mexico's Next Crisis will Arrive from the South', Council on Foreign Relations, July 9, 2018, available at https://www.cfr.org/blog/mexicos-next-crisiswill-arrive-south?sp_mid=56960709\&sp_rid=Y2Flc29sYXJAZ21haWwuY29tS0 (accessed May 2019).

${ }^{66}$ U.S. State Department. 'U.S. Strategy for Central America', 2019, available at https : //www.state.gov/p/wha/rt/strat/index.htm (accessed May 2019).

${ }^{67}$ United Nations Office on Drugs and Crime (UNODC). 'Transnational Organized Crime in Central America and the Caribbean: A Threat Assessment', 2012, available at: https://www. unodc.org/documents/data-and-analysis/Studies/TOC_Central_ America_and_the_Caribbean_english.pdf (accessed May 2019).

${ }^{68}$ Binay Prasada. 'A Latin American battle: China vs. Taiwan', The Diplomat, August 19, 2017, available at https://thediplomat.com/2017/08/a-latin-american-battlechina-vs-taiwan/ (accessed May 2019).

${ }^{69}$ Erwan De Cherisey. 'Taiwan Donates Military Equipment to Dominican Republic', Jane's, October 31, 2017, available at: http://www.janes.com/article/75347/taiwandonates-military-equipment-to-dominican-republic (accessed May 2019).

${ }^{70}$ Frank Chen. 'Arms Donation used by Taipei to Help Allies Stay Loyal', Asian Times, November 6, 2017, available at http://www .atimes.com/article/arms-donationsused-taipei-help-allies-stay-loyal/ (accessed May 2019).

${ }^{71}$ See Permanent Mission of the People's Republic of China to the UN (PMPRC). 'Statement by Mr. Sun Lei, counsellor of the Permanent Mission of China to the UN, at the general debate of the United Nations Disarmament Commission 2017 Substan- 
tive Session', April 3, 2017, available at: http://www.china-un.org/eng/chinaandun/ disarmament_armscontrol/t1451169.htm (accessed May 2019).

${ }^{72}$ Foreign Ministry of the People's Republic of China (FMPRC). 'Foreign Ministry Spokesperson Hong Lei's Regular Press Conference', March 1, 2015, available at: http://www.fmprc.gov.cn/mfa_eng/xwfw_665399/s2510_665401/t1246058.shtml (accessed May 2019).

${ }^{73}$ To recapitulate these pillars are: "The exports should be conducive to the legitimate self-defence capability of the recipient country; the exports should not undermine the peace, security and stability of the region concerned and the world as a whole; and the exports should not be used as a means of interfering in the internal affairs of the recipient country." See FMPRC, 'China's Defense Policy'.

${ }^{74}$ This information is available at Foreign Ministry of the People's Republic of China (FMPRC). 'The 8th China-US Consultation on Strategic Security and Multilateral Arms Control held in Washington D.C.', May 13, 2016, available at http://www.fmprc.gov.cn/ mfa_eng/wjb_663304/zygy_663314/gyhd_663338/t1364019.shtml (accessed May 2019). A month later to the U.S.-China consultation in Washington, Xi Jinping and Vladimir Putin signed at the Great Hall of the People in Beijing a joint statement vowing to strengthen "global strategic stability", which argued that "arms control is an important means to strengthen global security and stability, and that disarmament and arms control should be fair and balanced, and be conducive for every country's security." See Xinhua. 'China, Russia Sign Joint Statement on Strengthening Global Strategic Stability,' June 26, 2016, available at http://www.xinhuanet.com/english/2016-06/26/c_135466187.htm (accessed May 2019). 